\title{
Mitigation of Deer Herbivory in Temperate Hardwood Forest Regeneration: A Meta-Analysis of Research Literature
}

\author{
Caleb H. Redick $(\mathbb{1}$ and Douglass F. Jacobs *(1) \\ Department of Forestry and Natural Resources, Hardwood Tree Improvement and Regeneration Center, \\ Purdue University, West Lafayette, IN 47907, USA; credick@purdue.edu \\ * Correspondence: djacobs@purdue.edu
}

Received: 21 September 2020; Accepted: 16 November 2020; Published: 19 November 2020

\begin{abstract}
Ungulate herbivory poses global challenges to forest regeneration. Deer, in combination with other biotic and abiotic factors, threaten to shift forest composition away from palatable hardwoods, such as oaks (Quercus spp.), and cause regeneration failure in some cases. Many studies have assessed methods to reduce or manage browse, but comprehensive analyses of the relative effectiveness of these techniques among published experiments are lacking. We synthesized the literature describing the results of methods to reduce deer browsing impacts, and assessed the effectiveness of deer browse management methods in controlling damage to hardwood forest regeneration. Specifically, we systematically analyzed results from 99 studies that used repellents, physical barriers, lethal population control, timber harvests, facilitation by neighboring plants, or fertilizer to affect browse, survival, or height growth of hardwood seedlings. Across studies, browse was reduced (mean effect size and confidence intervals) with the following: Fencing -3.17 (CI: $-4.00--1.31$ ), shelters -1.28 (CI: $-2.02-0.67)$, cages -1.48 (CI: $-3.14-0.62)$, facilitation from neighboring plants -0.58 (CI: $-1.11-0.13)$, repellents -0.45 (CI: $-0.56-0.21$ ), hunting -0.99 (CI: $-1.51-0.26)$. These methods each had positive effects on seedling height growth (except for repellents), and cages, timber harvests, fences, and mesh sleeves had positive effects on survival. Logging slash had no effect on browse incidence $(-0.05, \mathrm{CI}:-0.97-0.19)$. Fertilizer applied during seedling establishment increased browse (0.13, CI: 0.11-0.21), and did not affect height growth. We conclude that fences or other physical barriers best control for the effects of deer, but facilitation by surrounding vegetation, logging slash, hunting, habitat management through timber harvest, and certain repellents may also be moderately effective. Discrepancies between browse effectiveness and relative costs suggest that economic analyses should be developed to help to guide prescriptions for management.
\end{abstract}

Keywords: animal browse; fencing; fertilization; oak regeneration; plant facilitation; reforestation; repellents; tree shelters

\section{Introduction}

Deer herbivory resulting from high deer populations poses a major obstacle to temperate hardwood forest regeneration globally [1-3]. In some cases, deer can prevent the whole stands from maturing. Deer herbivory stunts tree growth, slowing the growth of desired tree species, and allowing herbaceous species to outcompete seedlings [4]. In addition, deer often browse terminal buds [5], reducing the quality of the timber by causing lateral buds to grow into multiple leaders [6]. In regions where markets put a premium on straight boles, this can decrease tree value, posing an even greater challenge to forest management. Browsing tends to favor some species over others, changing community composition [7-10]. For example, high-value hardwoods, such as oaks, are often selected 
by white-tailed deer in higher proportions relative to their availability compared to other species, such as ash and maple [9]. Deer may even shift forest ecosystems to alternative stable states dominated by ferns, grasses, or shrubs from which they cannot recover without intervention [11-13]. For example, in the eastern U.S., white-tailed deer browse any palatable trees that grow above the competing vegetation, and may reduce coverage of Rubus spp., which would otherwise compete with ferns and grasses and allow desired trees to grow [11,12].

There is much debate regarding the desirable density of deer. Deer have positive and negative economic impacts and effects on ecosystem services that must be weighed [14]. A total solution to the problem is not possible; deer will cause damage to species desired by land managers even at relatively low population densities, yet also represent hunting, aesthetic, and intrinsic value. In addition, populations close to historic densities $\left(<8\right.$ deer per $\mathrm{km}^{2}$ for white-tailed deer in the eastern U.S.) have positive effects on plant diversity [15,16]. Tilghman et al. [17] controlled the density of white-tailed deer (Odocoileus virginianus) within large enclosures in northwestern Pennsylvania and found that densities above 7-11 per $\mathrm{km}^{2}$ resulted in the failure of desirable species (e.g., sugar maple (Acer saccharum), red maple (Acer rubrum), white ash (Fraxinus americana), and birch (Betula spp.)) to regenerate in clear-cuts, and similar trends were found in thinned treatments. In addition, the cover of competing vegetation, such as ferns, was higher in clear-cuts at high deer densities [17]. Csigi and Holzmueller [18] found that white-tailed deer densities between 6 and 12 deer per $\mathrm{km}^{2}$ resulted in the reduced height of hardwood seedlings in southeast Illinois. The carrying capacity of a forest and the habitat structure also affect the deer population levels that produce "damage" [19]. Population reduction can be used to reduce damage; however, deer may be maintained at higher densities, due to a desire for more deer and/or low hunter participation. In addition, reducing populations may not solve the issue, as in the case of an alternative stable state. In these cases, other browse management methods are needed.

Many studies on browse management methods have been published in the scientific literature, but there is a need for practice-oriented reviews of this research that are relevant to forest management. Forest managers are desperate for cost-effective browsing control solutions, and may not be aware of the scientific research behind alternative management solutions. Beguin et al. [20] published one such study, focused on global temperate and boreal forest regeneration, but, to our knowledge, no studies have systematically compared the effectiveness of methods using published data across experiments. In addition, much of the research on this topic has emphasized conifers with less attention paid to temperate hardwood forest systems. Thus, our objectives in this paper were to: (i) Review and summarize the benefits of different browse control methods in temperate hardwood forests, along with their drawbacks and limitations; and (ii) systematically evaluate and compare the relative effectiveness of browse control methods to aid temperate hardwood forest regeneration.

\section{Methods}

We reviewed the scientific literature on herbivory management methods for regenerating temperate hardwood forests and summarized the relative effectiveness of the control techniques. Between December 2019 and August 2020, we performed a systematic search to obtain abstracts in the electronic database Web of Science. The identified studies covered relevant subjects (temperate hardwood afforestation and reforestation projects), interventions (manipulation or mitigation of deer herbivory of seedlings or saplings through browse management, repellents, population control (sport hunting and culls were both considered), cultural methods, or fertilization), and outcomes (regeneration and growth of seedlings or saplings). The range of publication dates was restricted to 1864-2019. Only studies with full-texts in English were included in the meta-analysis. Additional studies following our criteria were obtained from the bibliographies of selected articles. Table 1 presents the search terms. 
Table 1. Search terms used in the systematic search of the electronic database Web of Science. Asterisks (*) are wildcard operators.

\begin{tabular}{c} 
Search Terms \\
\hline$\left(\left(\right.\right.$ deer OR ungulate OR brows $\left.^{*}\right)$ AND (forest* OR reforest* OR woodland OR hardwood) AND ${ }^{*}$ brows $^{*}$ OR \\
fenc ${ }^{*}$ OR exclos* OR repell* OR facilitation OR tree shelters OR population control OR hunt* OR fert* OR \\
herbiv $^{*}$ OR deterr* OR slash OR timber harvest OR clearcut) AND $\left({ }^{*}\right.$ regen* OR hardwood OR refor $\left.{ }^{*}\right)$ NOT \\
(conifer OR tropical OR boreal))
\end{tabular}

After our search, 147 publications were retained for full-text assessment. Of these publications, 99 met all of the research criteria listed above and contained usable data on browse incidence, survival, or height growth (Supplementary Materials). These were reviewed and retained for data extraction, mostly from the United States (72), but including Canada (7), Japan (5), Spain (4), Poland (2), Sweden (2), Great Britain (1), Italy (1), Australia (1), Czechia (1), Ireland (1), France (1), and New Zealand (1). Some of these studies presented results on multiple species, management methods, or sites; a total of 42 height growth entries, 93 survival results, and 95 browse entries were recorded. Browse management methods were grouped into several broad categories, including fences, repellents, shelters, sleeves (similar to shelters, but made of fabric or mesh), cages, facilitation (planting trees with shrubs, weeds, or other trees to attempt protection or defense), fertilizers, lethal population control, timber harvest (to increase forage and decrease plant apparency), or slash (as a barrier). Figure 1 illustrates some of the browse management methods commonly encountered in the literature.
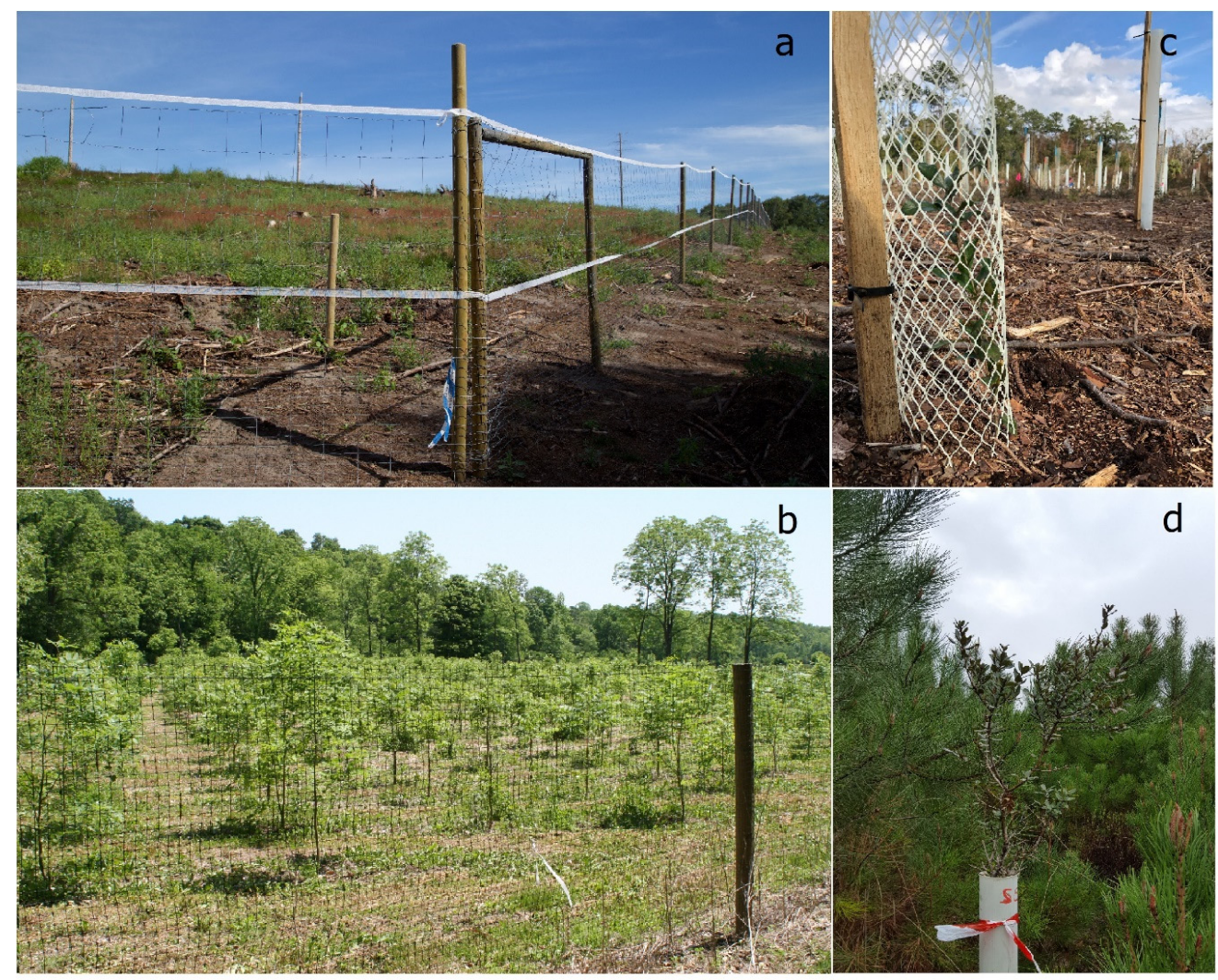

Figure 1. Illustrations of some of the browse management methods commonly encountered in the literature: Wire fencing with Quercus robur in southern Sweden (a), plastic mesh fencing for Juglans nigra in Indiana, USA (b), mesh sleeves on Quercus virginiana in coastal Georgia, USA (c), and solid-walled tree shelters on planted Querus ilex combined with plant facilitation from Pinus pinaster natural regeneration on the northern coast of Tuscany, Italy (d). Photo credits: D.F. Jacobs (a-c) and B. Mariotti (d). 
Means $( \pm$ SE) of height growth, survival, or browse were obtained from tables and publication texts (peer-reviewed and non-peer-reviewed); some papers did not directly report measurements, but provided enough data for values to be calculated. Results sometimes had to be indirectly taken from plots or histograms. In these cases, Plot Digitizer [21] was used. Hedge's G was calculated as a measure for "effect size" for the difference in height or growth between control and treatment means. Hedge's G (Formula (1)) is used for studies with small or variable sample sizes, where $s_{1}$ represents the standard deviation of the treatment group, $s_{c}$ represents the standard deviation of the control group, $\mathrm{n}_{1}$ represents the sample size of the treatment group, and $n_{c}$ represents the sample size of the control group [22]. 95\% confidence intervals (CI) were produced using the standard error of Hedge's G, as described in Turner and Bernard [22].

$$
\text { Hedge' s G }=\frac{\text { Treatment Mean }- \text { Control Mean }}{\sqrt{\frac{\left(n_{1}-1\right) s_{1}^{2}+\left(n_{c}-1\right) s_{c}^{2}}{\left(n_{1}-1\right)+\left(n_{c}-1\right)}}} \times \frac{n_{1}+n_{c}-3}{n_{1}+n_{c}-2.25} \sqrt{\frac{n_{1}+n_{c}-2}{n_{1}+n_{c}}}
$$

Few studies reported a measure of variance for browse or survival, thus we used control means and treatment means to obtain log response ratios (Formula (2)) as an effect size for browse and survival [23].

$$
\text { Log Response Ratio }=\ln \left(\frac{\text { Treatment Mean }}{\text { Control Mean }}\right)
$$

We then obtained inverse variance weights from sample sizes using Formula (3), and performed bootstrapping using R statistical software [24] to produce confidence intervals [23]. For bootstrapping, we used the boot package [25], using 9999 permutations of the data.

$$
\text { Inverse Variance Weight }=\frac{n_{1} n_{\mathcal{c}}}{n_{1}+n_{c}}
$$

Following Paquette et al. [26], for studies reporting multiple treatments, values were considered independent observations if they involved different browse management methods or experimental methods. In cases where multiple browse management methods were tested, however, values were only taken from independent treatments whenever possible; interactions were avoided. Values reported for different species within an experiment were combined. Results for planted seedlings, as well as natural regeneration, were included, though most (69\%) studies reported on planted seedlings. Stump sprouts were excluded from growth analyses, and direct seeding and top-cut seedlings were excluded from all analyses.

Over half of the fencing treatments had no browse, resulting in infinite log response ratios that had to be dropped from analyses. Therefore, in addition to the log response ratios, we also used the absolute difference between control means and treatment means to get another "effect size" for browse [22]. These differences are reported in the text as "reductions in browse." We performed unweighted randomization tests on these differences between experimental treatments and controls (calculated from published results) to test for a significant relationship between browse management method and browse [26]. This randomization test used test statistics from ANOVA. This test was computed in R statistical software [24] using the reshape2 and vegan packages, using 9999 permutations of the data (plus one of the original datasets) [27,28].

Following Turner and Bernard [22], the significance of the effect on height growth was assessed by examining the $95 \%$ confidence intervals for Hedge's $\mathrm{G}$. If the confidence interval did not include zero, the effect was considered significant. The same method was used to assess significance for effects on survival and browsing, utilizing 95\% confidence intervals for the log response ratios.

\section{Results}

Most browse control treatments had the intended effect of decreased browse (Figure 2). When differences in browsing observed between the experimental treatments and the control groups 
were used, these differences did not have a significant relationship with the management method used, according to ANOVA ( $p=0.063$ ). Despite this, the confidence intervals for many of the effect sizes we calculated using log response ratios were above zero, indicating significant effects.

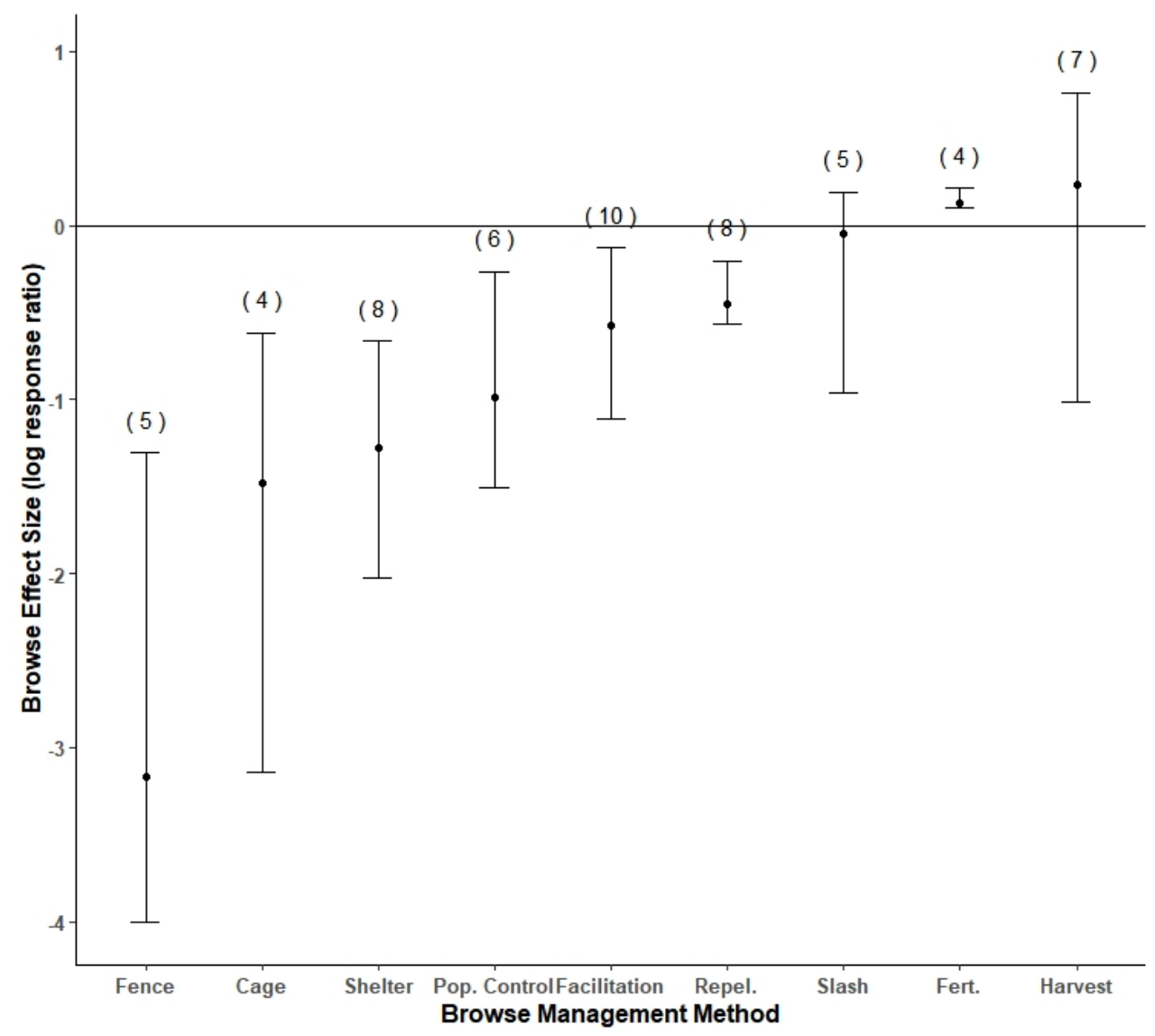

Figure 2. Mean and 95\% confidence limits of browsing effect size (log response ratio) among nine categories of browse management. Numbers in parentheses represent the number of individual studies used for each method.

Fencing resulted in the largest log response ratio (mean, 95\% confidence range; $-3.17,-4.00-1.31$; negative numbers indicate a reduction in browsing; Figure 2), even though the fencing treatments that resulted in a total absence of browse (and, therefore, had an infinite log response ratio) were excluded. Although inadequate fence height can result in failure, removing fences below $1.8 \mathrm{~m}$ from the analysis had little effect on the results $(-3.49,-4.03--2.09)$. Among the fencing options, plastic mesh fencing was most effective, when all fencing was analyzed, with a browse reduction of $56.3 \pm 24.8 \%$ (mean $\pm \mathrm{SE}$ ). However, wire fencing, which is more expensive, had a browse reduction of $47.9 \pm 10.9 \%$, and was the most effective option (browsing reduction of $61.0 \pm 9.3 \%$ ) when fences below $1.8 \mathrm{~m}$ were removed. Electric fencing reduced browsing incidence by $25.5 \pm 7.5 \%$, and barbed wire reduced browsing incidence by $18 \%$ in one study.

Population control resulted in a relatively large log response ratio for browsing $(-0.99,-1.51--0.26$; Figure 2). Timber harvests had no significant effect on browsing in the studies we analyzed (0.23, -1.01-0.76; Figure 2). Slash also had no significant effect on browsing (-0.05, $-0.97-0.19$; Figure 2). Cages resulted in a relatively large browsing log response ratio $(-1.48,-3.14--0.62$; Figure 2).

Tree shelters can be solid-walled or mesh (Figure 1). We separated the two types in our survival and growth analyses. However, we combined solid-walled shelters and fabric or mesh sleeves into one category for the browse analysis because of a dearth of studies reporting on browsing incidence for these methods. Shelters were the third most effective browsing management method, after fencing and 
cages (-1.28, -2.02--0.67; Figure 2). Three of the observations used $60 \mathrm{~cm}$ shelters, allowing deer to reach the buds that grew out of the shelter. When these shorter shelters were excluded, shelters became the second most effective method for reducing browsing $(-1.69,-2.20--0.87)$. The best performing shelters in our analysis were $150 \mathrm{~cm}$ tall (a mean browsing reduction of $68.5 \pm 22.5 \%$ ).

Repellents resulted in a moderate log response ratio for browsing $(-0.45,-0.56--0.21$; Figure 2$)$. Among repellents, ammonium soap salts of higher fatty acids most consistently reduced browsing $(44.0 \pm 5.0 \%)$. Putrescent egg solids were also as effective $(38.3 \pm 10.9 \%)$. Soap, tested in one study with many brands, was the least effective repellent (2.3\%). Facilitation by other plants resulted in a moderate $\log$ response ratio for browsing $(-0.58,-1.11--0.13$; Figure 2). Fertilizers increased browsing $(0.13$, 0.11-0.21; Figure 2).

For survival as a response variable, the browse control methods had very large confidence intervals (Figure 3). Mortality from deer browsing often results from cumulative stress rather than an immediate response [29], which may explain the large variation in the effectiveness of management methods. While browsing indirectly contributes to mortality by making trees less competitive, some trees can survive years of browsing in stunted form, and most experiments do not last more than five years.

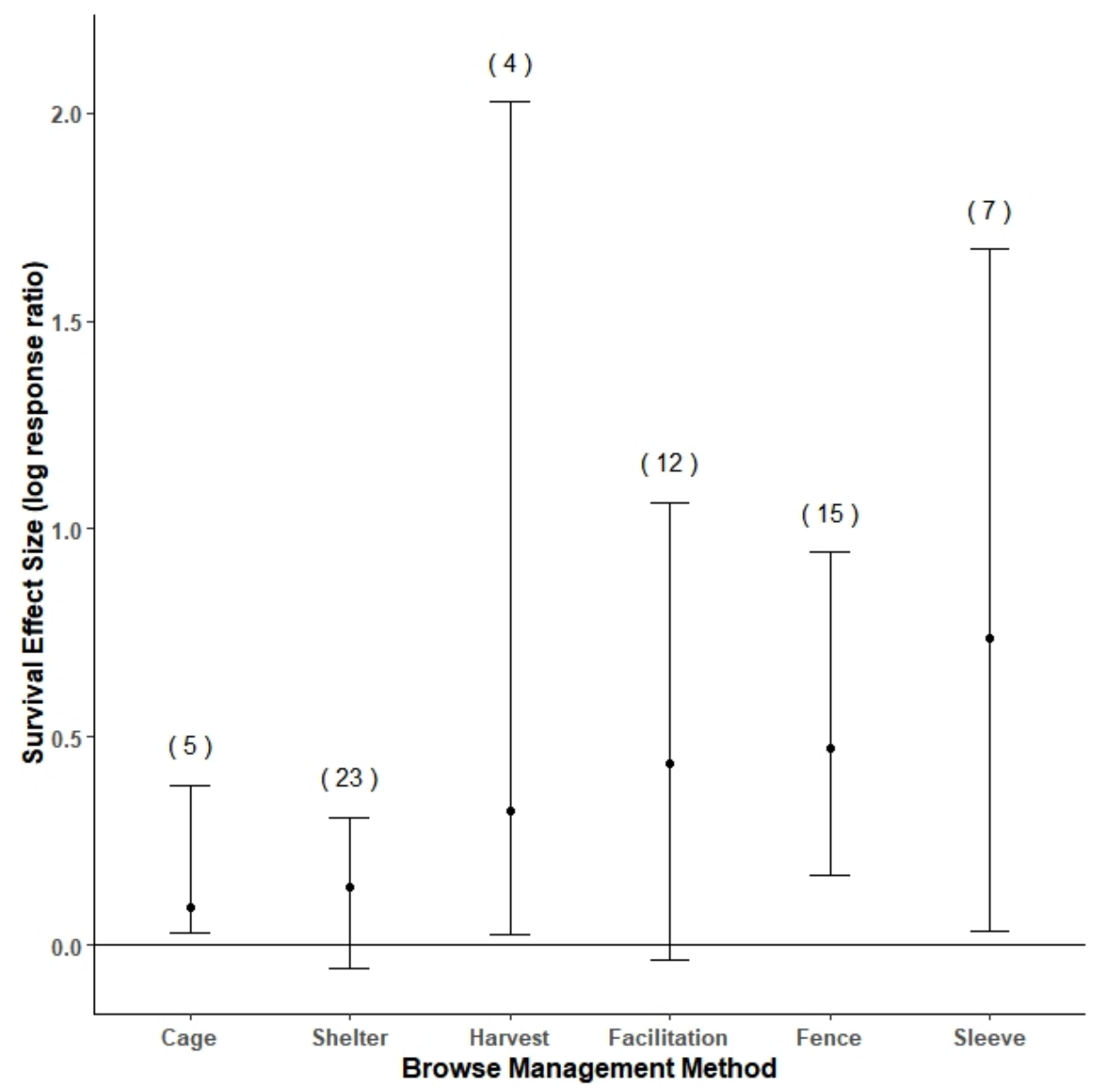

Figure 3. Mean and $95 \%$ confidence limits of survival effect size (log response ratio) among seven categories of browse management. Numbers in parentheses represent the number of studies used for each method.

Timber harvests had a variable effect on survival (0.32,0.03-2.03; Figure 3$)$. Fencing had a moderate effect on survival $(0.47,0.17-0.94$; Figure 3$)$. In two fencing studies that reported negative effects of fencing on survival, factors other than deer browsing were suggested as causal mechanisms. These factors were drought and digging by squirrels [30], and higher transpiration rates, due to greater 
leaf area in the absence of herbivory [31]. Removing these studies, as well as those with fencing below $1.8 \mathrm{~m}$, had little change in survival log response ratio, however $(0.55,0.14-1.09)$. Solid-walled shelters did not affect survival $(0.14,-0.06-0.31)$, but mesh sleeves positively affected survival $(0.74,0.03-1.67$; Figure 3), and removing $60 \mathrm{~cm}$ shelters and sleeves did not change this (shelters: $0.14,-0.06-0.31$; sleeves: $0.85,0.04-1.79$, respectively). Cages had a small effect on survival $(0.09,0.03-0.38$; Figure 3$)$. Facilitation had no significant effect on survival $(0.44,-0.04-1.06$; Figure 3). Only one experiment studied the effects of repellents on survival (though it studied four different repellents), and it resulted in a very small log response ratio (0.04). Only one experiment, following our criteria, studied the effects of fertilizer on survival in the presence of deer; it resulted in a small log response ratio (0.04).

All methods analyzed, except for fertilizer, had a significant, positive effect size on height or height growth (Figure 4). Fencing had a height growth effect size of 0.52 (CI: 0.42-0.62; Figure 4). After removing fences below $1.8 \mathrm{~m}$, the log response ratio decreased slightly $(0.48,0.38-0.58)$. Shelters had an effect size on height growth of 0.64 (CI: 0.57-0.71; Figure 4). Cages had the greatest effect size on height growth $(1.24,0.92-1.56)$. However, the effects of cages on growth were reported by only two studies. Repellents had a height growth effect size of 0.59 (CI: 0.00-1.18; Figure 4), but few studies with repellents reported on the growth and associated variance (i.e., only one, which examined two repellent types, could be used for this analysis). The $95 \%$ confidence interval for the growth effect size of fertilizers included zero, indicating no significant effect $(-0.17,-0.46-0.12$; Figure 4$)$; however, the growth effects of fertilizer were reported by only two studies fitting our criteria. Facilitation had a height growth effect size of 0.30 (CI: 0.17-0.43; Figure 4).

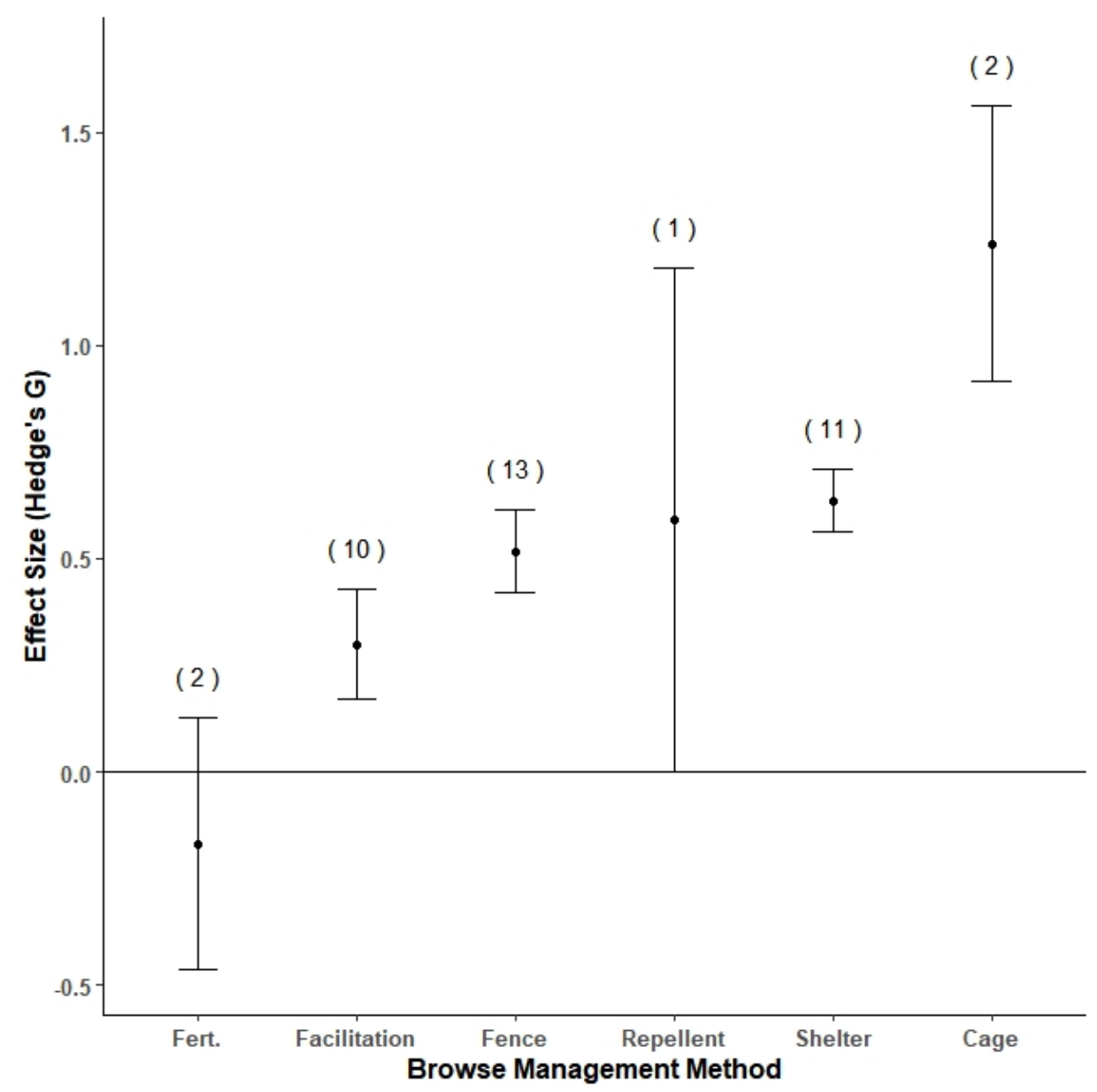

Figure 4. Mean and 95\% confidence limits of height growth effect size (Hedge's G) among six categories of browse management. Numbers in parentheses represent the number of individual studies used for each method. 


\section{Discussion}

\subsection{Deer Population Control and Timber Harvest}

Controlling deer populations through culls or sport hunting is the most direct method of addressing damage by deer; and such control methods have been successful in some cases [10,32,33]. Our results indicated that population control was an effective means of controlling browse, but less so than most physical barriers (Figure 2). Population control can be hard to implement, and even small populations of deer can continue to have effects after prolonged browse [10,34]. For example, although sapling densities in New Zealand forests are recovering after decades of culling ungulates, preferred tree species are still being affected [34]. Miller et al. [35] found that localized removal of a matriarchal social unit of white-tailed deer in West Virginia was ineffective because deer subsequently colonized from surrounding areas. Instead, browsing was more affected by forage availability whereby increasing natural forage due to timber harvests resulted in decreasing browsing incidence of monitored hardwoods. Tanentzap et al. [10], on the other hand, did find increases in seedling density in Ontario following reductions of white-tailed deer density from $>30$ to 7 per $\mathrm{km}^{2}$. The forest still had not recovered to the conditions prevailing before the deer population reached 30 per $\mathrm{km}^{2}$, however, indicating that recovery can take long periods of time. Changing policy to increase deer harvest by sport hunting has been successfully used in Germany to reduce browse of hardwoods in as little time as three years [32]. To be effective, hunting must be used at a sufficient pressure over multiple years with a high density of hunters killing antlerless deer in accessible areas [36]. Though necessary to address the problem of deer overpopulation, methods other than hunting or sharpshooting to manage deer browsing, such as physical barriers, facilitation by neighbors, or increases in forage may be required until populations are reduced on a regional level.

Reducing deer damage to forest regeneration can be accomplished not only by decreasing the numbers of deer in an ecosystem, but also by increasing the amount of alternative forage available to the deer. Marquis et al. [37] suggested that sufficient timber harvests could allow enough regenerating trees to escape deer herbivory by producing more food than the deer can consume. Reimoser and Gossow [19] similarly suggested that using shelterwoods, rather than clear-cuts, can allow advance regeneration to survive in the presence of deer. Timber harvests had no significant effect on browsing in the studies we analyzed and had a variable, though positive, effect on survival (Figure 3). This is likely because timber harvesting is a broad category, and its effect on deer browsing is context-dependent. Clearcuts that are too small can allow even a few deer to negatively influence regeneration [19]. The hypothesis that carefully planned timber harvest can reduce deer damage has been supported in several studies [38-41]. Walters et al. [42] found that this reduction in browsing by white-tailed deer occurs when vegetation is left intact, but browsing increased with increasing harvest area in mechanically weeded plots. Akins and Michael [38] examined a range of sizes for harvest openings and suggested that they be made $>0.8$ ha to allow a sufficient number of stems to escape white-tailed deer browse. Without management of deer populations in the long term, however, an increase in food abundance will have the effect of increasing carrying capacity, and thus, deer populations, exacerbating the problem. The simultaneous combination of hunting to reduce deer populations and timber harvest was tested in West Virginia [39] and resulted in a reduction of browsing to levels usually considered acceptable for regeneration. In another study, a combination of shelterwood cuts, control of competing vegetation, and white-tailed deer population reduction below 5.2 deer per $\mathrm{km}^{2}$ was required for desirable regeneration in northern hardwood forests of New York [43]. More experiments are needed to determine the relative effects of population control and timber harvesting, but these studies illustrate the importance of careful planning before implementing silvicultural projects [42], and that a combination of methods is often the best option for successful hardwood regeneration. 


\subsection{Physical Barriers}

In combination with (or in the absence of) management focused on deer populations, a myriad of methods can be implemented to protect seedlings from damage. Fencing has a high cost, but we found it to be one of the most effective methods of reducing deer herbivory and can eliminate browse if sufficiently tall and maintained correctly (Figures $2-4$ ). Fencing should be tall enough that the target deer species cannot easily jump over it, taking snow accumulation into account in relevant regions. In addition, flagging tied to the fence aids visibility and prevents deer from running into and breaking the fence. Curtis et al. (1994) provide information on costs and materials for various types of fencing [44]. Common options include woven wire fences, plastic mesh fences, and electrified fences (Figure 1). Wire and mesh fences reduced browsing more than electric fences in the studies we collected. It should be noted that fencing can also have a negative effect on seedlings by freeing competing vegetation from deer browse, as in the case of a study in Michigan that found less browsed tree species were benefited by deer because competing Sambucus shrubs had lower density outside fences (though fencing still had a positive effect on tree species that were browsed more) [42]. Slash piles have also been used successfully as physical barriers around patches of regeneration [45-47], but Kota and Bartos [48] found that, though more effective than no treatment, slash piles were no more effective than livestock fences. In our analysis, slash had no significant effect on browsing (Figure 2). One study reported that slash actually increased browsing in northeastern France, possibly by increasing visibility to roe deer (Capreolus capreolus) and red deer (Cervus elaphus) [49]. Kota and Bartos [48] found that "hinge barriers," in which trees are partially cut down and left connected to the stump to form barriers around patches of regenerating seedlings, were effective against white-tailed deer, elk (Cervus canadensis), and cattle (Bos taurus), though not as effective as woven wire fencing. These hinge barriers also increased recruitment into higher size classes at a greater rate than fencing (possibly due to reduced evapotranspiration from shading) [48].

Solid-walled tree shelters were invented in Britain in the 1980s for the purposes of protection against herbivory, the creation of a greenhouse effect, and assisting weed control [50]. These first solid-walled shelters consisted of plastic mesh wrapped in polyethylene, but since then, a range of options with varying materials and colors have been used. They have been shown in many studies to be effective for increasing hardwood growth $[51,52]$ and survival $[53,54]$, and allowing more seedlings to reach free-to-grow status (height above which deer can no longer browse the terminal bud, and above which trees are free from understory competitors $[55,56])$. In our analysis, shelters were effective at decreasing browsing and increasing growth, but had no consistent effect on survival (Figures 2-4). Many of these studies were conducted on northern red oak (Quercus rubra) [52,53], though a range of species has been studied in combination with different management methods. Shelter height and type affect success. Some studies have found that shelters $\leq 0.6 \mathrm{~m}$ high do not have beneficial effects because deer can reach terminal buds $[57,58]$. Indeed, in one study, $60 \mathrm{~cm}$ Blue- $X^{\circledR}$ shelters increased white-tailed deer browsing of silver maples, possibly by increasing the visibility of seedlings [57]. However, a study that used direct seeding found beneficial effects of short Tubex ${ }^{\circledR}$ shelters [53]. The propriety of shelter height depends on the height of the seedlings planted, and Keeton et al. [57] suggest using shelters at least $0.5 \mathrm{~m}$ taller than the seedlings. Despite this, shelters of the same height as seedlings may still be beneficial, because white-tailed deer can only browse the portion emerging from the shelter [59]. Among the different heights that were included in the studies, we found that the most effective at reducing browsing were $150 \mathrm{~cm}$ tall. Diameter and type of polymer used to make the shelters have little effect on growth [50]. Fabric and mesh sleeves tend to have an intermediate effect on temperature and light, and also tend to have less of an effect on height growth [51,52], though one study found that they increase diameter growth [60]. We found that sleeves had a variable, but positive effect on survival (Figure 3). Cages, another barrier option, also do not create a greenhouse effect, but are more durable than mesh sleeves, and can be reused [55,61]. We found that cages were effective at decreasing browsing, and increasing growth and survival (Figures 2-4). Disadvantages of shelters and other physical barriers include impeded or distorted growth, as well as inhibition of light 
transmittance, but these can be mitigated by supporting them with stakes and/or removing shelters before they inhibit growth [62].

\subsection{Repellents}

Repellents are a common alternative to physical barriers; however, they are short-lived (i.e., the most effective repellents last $\sim 3$ months) [63]. In 1994, federally listed deer repellents in the U.S. included ammonium soaps of higher fatty acids, bone tar oil, capsaicin, denatonium saccharides, putrescent egg solids, and thiram [64]. We found experiments testing all of these repellents except for bone tar oil, as well as many other contact repellents (both commercially available and homemade). We found that repellents were effective at reducing browse incidence, but less effective than fences (Figure 2). Among commercially available repellents, putrescent egg solids have been shown to be effective in several studies [65-68]. Only hydrolyzed casein (in a study on western redcedar) and human hair (in a study on apple orchards) were more effective $[67,69]$. Though predator urines are also now commercially available, no studies were found fitting our criteria. The effectiveness of repellents depends on the weather, deer density, and availability of alternative food sources. Putrescent egg solids reduced white-tailed deer browsing of apple (Malus domestica) trees by about 50\% (up to 76\% for yews (Taxus cuspidate)), while in another experiment comparing repellents to shelters, putrescent egg solids and concentrated edible animal protein failed to have a significant effect on oak survival [55]. Repellents must be reapplied periodically to maintain their effectiveness; however, deer may become accustomed to them, especially if there is little alternative food. One study successfully overcame this by using multiple repellents, although browsing incidence was only measured during summer [70]. Systemic repellents have been tested (e.g., controlled release selenium or capsaicin tablets), but success depends upon uptake of the chemical. Gustafson [71] found that selenium was successfully taken up by several hardwood species and that it reduced deer browse of Douglas-fir (Pseudotsuga menziesii) seedlings by half when all seedlings were treated. There is a dearth of peer-reviewed literature documenting research on repellents and hardwoods. Much of the research on repellents was conducted with conifers or is grey literature. Some of the research on repellents from southern and eastern Europe has not been translated into English [72,73].

\subsection{Fertilizers}

Fertilization at planting may promote the growth of seedlings above the browse line, or may aid seedlings in recovery from browse, especially on nutrient-limited sites [46,74]. Some studies have shown, however, that fertilizer increases browse by increasing palatability to deer or by increasing site attractiveness $[75,76]$. Our analysis indicated that fertilizer significantly increased browse incidence (Figure 2), and did not affect growth (Figure 4). This indicates that the benefits of fertilizer on growth are likely offset by herbivory in the studies we collected. Burney and Jacobs [31] found that fertilization at planting only increased the growth of seedlings inside fenced treatments, and Brinks et al. [77] found broadcast granular fertilizer aided the growth of American sycamore (Platanus occidentalis) on reclaimed mine sites, but not black locust (Robinia pseudoacacia), likely because of elk preference for locust (76\% of which were browsed), due to their high nitrogen concentrations. While it was published too late to be included in our analysis, Redick et al. [78] found similar results to Burney and Jacobs for black cherry (Prunus serotina). The consequences of fertilizer and browsing are highly species-dependent. Differences between species-specific herbivore response to elevated nitrogen concentrations (and, indeed, species preferences in general), may be due to different strategies for storing added nutrients, or different responses of defense compounds to fertilization $[74,76,79,80]$. Some species (e.g., black cherry, yellow birch (Betula alleghaniensis), sugar maple, and white ash) are "luxury consumers" that store extra nitrogen in existing tissues until it can be used for new growth, increasing the attractiveness of the plant to herbivores [76]. Fertilizers have also been shown to change concentrations of defense compounds in oaks, most often by decreasing tannins [79,80]. We conclude that fertilizers are not generally useful on their own as methods for overcoming the effects of browse, 
though more research could be done in this area. In combination with other methods, they may shorten the amount of time and maintenance needed for trees to reach free-to-grow status [78].

\subsection{Alternative Methods}

Aside from physical barriers, repellents, and fertilizers, there are several low-cost natural methods of mitigating deer herbivory. These include changing (sometimes avoiding) vegetation management or planting seedlings with other shrubs or trees to facilitate the target species. These methods had a small effect on browsing (less effective than fencing; Figure 2) and growth (less effective than cages and shelters; Figure 4), but had no consistent effect on survival (Figure 3). Vegetation, despite competing with seedlings, can thus reduce browsing by restricting access to seedlings. This was observed as early as 1915, when it was noted that elms (Ulmus spp.) could only survive in Ohio cattle pastures if they grew amid rosebushes (Rosa spp.), spicebush (Lindera benzoin), or other elms [81]. Similarly, Watt [82] indicated that oaks successfully regenerated in England when protected by shrubs or deer exclosures. Maltoni et al. [83] found that the ability of holm oak (Quercus ilex) to establish after emerging from tree shelters was facilitated by neighboring pine seedlings in the presence of fallow deer (Dama dama). Several studies indicate that weed control can make trees more visible to deer, and thus, increase browse and mortality $[42,53,58,59]$. The ability of neighboring vegetation to mitigate browsing depends on the relative palatability of the seedling and the neighboring vegetation, as well as herbivore pressure [84,85]. For example, in Mediterranean Spain, moderately unpalatable shrubs with spines protected palatable maples under moderate herbivore pressure, but not under high pressure, and shrubs increased the probability that unpalatable pines would be browsed [85].

Consideration must also be given to the competition from neighboring vegetation; the benefit of protection must outweigh the competitive cost. In Ohio, removal of Lonicera maackii shoots increased biomass and stem length in caged sugar maples, but decreased biomass, root:shoot ratio, and leaf area of uncaged trees (as well as leaf area of unprotected northern red oaks), possibly due to the protection from white-tailed deer browsing afforded by L. maackii [86]. Owings et al. [87] reported that the presence of L. maackii did not affect browsing of planted seedlings by white-tailed deer, and a negative effect on survival and growth, due to decreased light and water availability. Sweeney et al. [58] found that herbicide only resulted in greater survival in sheltered treatments, emphasizing the need for protection from deer for the success of other management methods. Another study found that herbicides and VisPore ${ }^{\circledR}$ weed mats aided the growth and survival of seedlings; however, by the final year, only sheltered seedlings had benefited [59]. Studies from Europe have shown that dense cover of some thorny shrubs, such as wild rose and hawthorn (Crataegus spp.), can deter browsing of shade-tolerant regenerating hardwoods by red deer and sika deer (Cervus nippon), but that the protective effects of other shrubs, such as blackthorn (Prunus spinosa), are outweighed by competitive effects [88]. A study in Michigan found that weeding reduced the height of fast-growing hardwood species in harvest gaps by exposing them to browsing by white-tailed deer, but that slow-growing species did not benefit [41]. In fact, they found that less browsed species were aided by deer, which increased light levels by browsing of competitors [41]. Another study on conifers found that deer positively impacted tree growth by browsing competitors (though those competitors were undesired hardwoods) [89]. Thus, the sensitivity of target species to browse should be considered before controlling competing vegetation. Indeed, before planting seedlings, species selection for trees that are less palatable or browse-tolerant can be used as another way of avoiding damage in the presence of deer [31], as deer prefer to browse some species over others, while more browse-tolerant species may be able to resist deer browse without a negative growth effect.

\section{Conclusions}

Based on our systematic literature review, fencing is clearly the most effective method for controlling browse of regeneration in temperate hardwood forests. Solid-walled tree shelters are also relatively effective, but only if the shelter height sufficiently protects seedlings until they reach 
free-to-grow height (between 120-150 cm for typical planting stock). Facilitation by other vegetation has a positive effect, and is better than no browse management when the cost of fencing and shelters are prohibitive, but did not outperform any other browsing control method. Facilitation is also highly dependent on context and on the relationship among the target species, facilitating plant species, and deer. While the use of cages, repellents, logging slash, habitat management through timber harvest, and lethal population control to reduce browse of hardwood species show promise, more research is needed to more clearly substantiate their likelihood of success under varying forestry systems. Of these methods, cages showed the greatest potential in the studies we found. Slash and timber harvest may not have the intended effect of browsing control if not implemented correctly, and have even increased browse in some cases. Fertilization at establishment showed no potential for reducing browsing damage and/or increasing growth in areas subject to high levels of herbivory, and in such cases, fertilizer benefits are only likely to be realized if ungulate browsing is controlled. However, the effects of fertilizer are species-dependent, and some species are not detrimentally affected. The most effective and desirable management method may be integrating multiple methods-including, but not limited to, deer population reduction and habitat manipulation.

Future studies of browsing control should take care to report sample size and variance, in addition to treatment and control means, as well as nonsignificant results, if they are to be useful in meta-analyses. In addition, studies of browse incidence and survival need sufficient replications to provide variance and sufficient sample size. Andiva et al. provide authors with guidelines on what information to include so that studies can be used effectively in future analyses [90].

Supplementary Materials: The following are available online at http://www.mdpi.com/1999-4907/11/11/1220/s1, Table S1. Characteristics of the studies used in the meta-analysis. Includes ungulate and tree species studied, browse management methods used, number of years the study lasted, number of effect sizes extracted from each study, and the type of responses. File: Studies Used in the Meta-Analysis.

Author Contributions: Conceptualization: C.H.R., D.F.J.; Data collection: C.H.R.; Data curation: C.H.R.; Formal Analysis: C.H.R.; Funding acquisition: D.F.J.; Investigation: C.H.R., D.F.J.; Methodology: C.H.R., D.F.J.; Project administration: D.F.J.; Resources: C.H.R., D.F.J.; Software: C.H.R., Supervision: D.F.J.; Validation: C.H.R., Visualization: C.H.R.; Writing—original draft: C.H.R.; Writing—review and editing: C.H.R., D.F.J. All authors have read and agreed to the published version of the manuscript.

Funding: This research was funded by the USDA National Institute of Food and Agriculture, McIntire Stennis project IND011535, Hardwood Tree Improvement and Regeneration Center, Fred M. van Eck Forest Foundation, and the Department of Forestry and Natural Resources at Purdue University.

Acknowledgments: We thank Lenny Farlee for his advice on searching for browse control methods. We are grateful to Tomas Höök for his advice on performing systematic reviews.

Conflicts of Interest: The authors declare no conflict of interest.

\section{References}

1. Kuijper, D.P.J.; Jędrzejewska, B.; Brzeziecki, B.; Churski, M.; Jędrzejewski, W.; Żybura, H. Fluctuating ungulate density shapes tree recruitment in natural stands of the Białowieża Primeval Forest, Poland. J. Veg. Sci. 2010, 21, 1082-1098. [CrossRef]

2. Petersson, L.K.; Milberg, P.; Bergstedt, J.; Dahlgren, J.; Felton, A.M.; Götmark, F.; Salk, C.; Löf, M. Changing land use and increasing abundance of deer cause natural regeneration failure of oaks: Six decades of landscape-scale evidence. For. Ecol. Manag. 2019, 444, 299-307. [CrossRef]

3. Takatsuki, S. Effects of sika deer on vegetation in Japan: A review. Biol. Conserv. 2009, 142, $1922-1929$. [CrossRef]

4. Putman, R.J.; Moore, N.P. Impact of deer in lowland Britain on agriculture, forestry and conservation habitats. Mammal Rev. 1998, 28, 141-164. [CrossRef]

5. Götmark, F.; Berglund, Å.; Wiklander, K. Browsing damage on broadleaved trees in semi-natural temperate forest in Sweden, with a focus on oak regeneration. Scand. J. For. Res. 2005, 20, 223-234. [CrossRef]

6. Jacobs, D.F.; Ross-Davis, A.L.; Davis, A.S. Establishment success of conservation tree plantations in relation to silvicultural practices in Indiana, USA. New For. 2004, 28, 23-36. [CrossRef] 
7. Akashi, N.; Unno, A.; Terazawa, K. Significance of woody browse preferences in evaluating the impact of sika deer browsing on tree seedlings. J. For. Res. 2015, 20, 396-402. [CrossRef]

8. Rooney, T.P. Deer impacts on forest ecosystems: A North American perspective. For. Int. J. For. Res. 2001, 74, 201-208. [CrossRef]

9. Strole, T.A.; Anderson, R.C. White-tailed deer browsing: Species preferences and implications for central Illinois forests. Nat. Areas J. 1992, 12, 139-144.

10. Tanentzap, A.J.; Bazely, D.R.; Koh, S.; Timciska, M.; Haggith, E.G.; Carleton, T.J.; Coomes, D.A. Seeing the forest for the deer: Do reductions in deer-disturbance lead to forest recovery? Biol. Conserv. 2011, 144, 376-382. [CrossRef]

11. Stromayer, K.A.K.; Warren, R.J. Are overabundant deer herds in the eastern United States creating alternate stable states in forest plant communities? Wildl. Soc. Bull. 1997, 25, 227-234.

12. Horsley, S.B.; Marquis, D.A. Interference by Weeds and Deer with Allegheny Hardwood Reproduction. Can. J. For. Res. 1983, 13, 61-69. [CrossRef]

13. Royo, A.A.; Carson, W.P. On the Formation of Dense Understory Layers in Forests Worldwide: Consequences and Implications for Forest Dynamics, Biodiversity, and Succession. Can. J. For. Res. 2006, 36, 1345-1362. [CrossRef]

14. Conover, M.R. Resolving Human-Wildlife Conflicts: The Science of Wildlife Damage Management; Lewis Publishers: Boca Raton, FA, USA, 2002; ISBN 978-1-56670-538-7.

15. Royo, A.A.; Collins, R.; Adams, M.B.; Kirschbaum, C.; Carson, W.P. Pervasive Interactions between Ungulate Browsers and Disturbance Regimes Promote Temperate Forest Herbaceous Diversity. Ecology 2010, 91, 93-105. [CrossRef] [PubMed]

16. Cook-Patton, S.C.; LaForgia, M.; Parker, J. Positive Interactions between Herbivores and Plant Diversity Shape Forest Regeneration. Proc. Biol. 2014, 281. [CrossRef]

17. Tilghman, N.G. Impacts of White-Tailed Deer on Forest Regeneration in Northwestern Pennsylvania. J. Wildl. Manag. 1989, 53, 524-532. [CrossRef]

18. Csigi XIV, K.K.; HolzmuelleRor, E.J. Reduced seedling height of hard mast species in areas with low deer densities in an oak-dominated forest. Ecol. Restor. 2015, 33, 19-21. [CrossRef]

19. Reimoser, F.; Gossow, H. Impact of ungulates on forest vegetation and its dependence on the silvicultural system. For. Ecol. Manag. 1996, 88, 107-119. [CrossRef]

20. Beguin, J.; Tremblay, J.-P.; Thiffault, N.; Pothier, D.; Côté, S.D. Management of forest regeneration in boreal and temperate deer-forest systems: Challenges, guidelines, and research gaps. Ecosphere 2016, 7. [CrossRef]

21. Huwaldt, J.A.; Steinhorst, S. Plot Digitizer (version 2.6.8). 2015. Available online: http://plotdigitizer. sourceforge.net/ (accessed on 13 April 2020).

22. Turner, H.M.; Bernard, R.M. Calculating and Synthesizing Effect Sizes. Contemp. Issues Commun. Sci. Disord. 2006, 33, 42-55. [CrossRef]

23. Koricheva, J.; Gurevitch, J.; Mengersen, K. Handbook of Meta-Analysis in Ecology and Evolution; Princeton University Press: New York, NY, USA, 2013.

24. R Core Team. A Language and Environment for Statistical Computing; R Foundation for Statistical Computing: Vienna, Austria, 2018.

25. Canty, A.; Ripley, B. Boot: Bootstrap R (S-Plus) Functions; R Package Version 1.3-22. Available online: https://cran.r-project.org/web/packages/boot/index.html (accessed on 28 October 2020).

26. Paquette, A.; Bouchard, A.; Cogliastro, A. Survival and Growth of Under-Planted Trees: A Meta-Analysis Across Four Biomes. Ecol. Appl. 2006, 16, 1575-1589. [CrossRef]

27. Oksanen, J.; Blanchet, F.G.; Friendly, M.; Kindt, R.; Legendre, P.; McGlinn, D.; Minchin, P.R.; O’Hara, R.B.; Simpson, G.L.; Solymos, P.; et al. Vegan: Community Ecology Package. Available online: https://cran.rproject.org/web/packages/vegan/index.html (accessed on 17 August 2020).

28. Wickham, H. Reshaping Data with the reshape Package. J. Stat. Softw. 2007, 21, 1-12. [CrossRef]

29. Russell, F.L.; Zippin, D.B.; Fowler, N.L. Effects of white-tailed deer (Odocoileus virginianus) on plants, plant populations and communities: A review. Am. Midl. Nat. 2001, 146, 1-26. [CrossRef]

30. Taggart, J.; Long, Z. Effects of White-Tailed Deer (Odocoileus virginianus) on the Maritime Forest of Bald Head Island, North Carolina. Am. Midl. Nat. 2015, 173, 283-294. [CrossRef]

31. Burney, O.T.; Jacobs, D.F. Species selection-A fundamental silvicultural tool to promote forest regeneration under high animal browsing pressure. For. Ecol. Manag. 2018, 408, 67-74. [CrossRef] 
32. Hothorn, T.; Müller, J. Large-scale reduction of ungulate browsing by managed sport hunting. For. Ecol. Manag. 2010, 260, 1416-1423. [CrossRef]

33. Jenkins, L.H.; Murray, B.D.; Jenkins, M.A.; Webster, C.R. Woody regeneration response to over a decade of deer population reductions in Indiana state parks. J. Torrey Bot. Soc. 2015, 142, 205-219. [CrossRef]

34. Wright, D.M.; Tanentzap, A.J.; Flores, O.; Husheer, S.W.; Duncan, R.P.; Wiser, S.K.; Coomes, D.A. Impacts of culling and exclusion of browsers on vegetation recovery across New Zealand forests. Biol. Conserv. 2012, 153, 64-71. [CrossRef]

35. Miller, B.F.; Campbell, T.A.; Laseter, B.R.; Ford, W.M.; Miller, K.V. Test of Localized Management for Reducing Deer Browsing in Forest Regeneration Areas. J. Wildl. Manag. 2010, 74, 370-378. [CrossRef]

36. Simard, M.A.; Dussault, C.; Huot, J.; Côté, S.D. Is hunting an effective tool to control overabundant deer? A test using an experimental approach. J. Wildl. Manag. 2013, 77, 254-269. [CrossRef]

37. Marquis, D.A.; Ernst, R.L.; Stout, S.L. Prescribing silvicultural treatments in hardwood stands of the Alleghenies. (Revised). Agric. For. Serv. Northeast. For. Exp. 1992, 96, 101.

38. Akins, J.W.; Michael, E.D. Impact of clearcut size on white-tailed deer use and tree regeneration. NCASI Tech. Bull. 1999, 2, 6-7.

39. Crimmins, S.M.; Edwards, J.W.; Ford, W.M.; Keyser, P.D.; Crum, J.M. Browsing Patterns of White-Tailed Deer Following Increased Timber Harvest and a Decline in Population Density. Int. J. For. Res. 2010, 2010. [CrossRef]

40. Miller, B.F.; Campbell, T.A.; Laseter, B.R.; Ford, W.M.; Miller, K.V. White-tailed deer herbivory and timber harvesting rates: Implications for regeneration success. For. Ecol. Manag. 2009, 258, 1067-1072. [CrossRef]

41. Walters, M.B.; Farinosi, E.J.; Willis, J.L.; Gottschalk, K.W. Managing for diversity: Harvest gap size drives complex light, vegetation, and deer herbivory impacts on tree seedlings. Ecosphere 2016, 7, e01397. [CrossRef]

42. Reimoser, F.; Putman, R. Impacts of Wild Ungulates on Vegetation: Costs and Benefits; Putman, R., Apollonio, M., Andersen, R., Eds.; Cambridge University Press: Cambridge, UK, 2010; ISBN 978-0-521-76059-1.

43. Sage, R.W.; Porter, W.F.; Underwood, H.B. Windows of opportunity: White-tailed deer and the dynamics of northern hardwood forests of the northeastern US. J. Nat. Conserv. 2003, 10, 213-220. [CrossRef]

44. Curtis, P.; Fargione, M.J.; Richmond, M.E. Preventing Deer Damage with Barrier, Electrical, and Behavioral Fencing Systems. In Proceedings of the Sixteenth Vertebrate Pest Conference, Santa Clara, CA, USA, 28 February-3 March 1994.

45. Hunn, J. Retention of Logging Debris to Reduce Deer Browsing and Promote Forest Regeneration. Bachelor's Thesis, College of Agriculture and Life Sciences, Department of Natural Resources, Cornell University, Ithaca, NY, USA, 2007.

46. Grisez, T.J. Slash Helps Protect Seedlings from Deer Browsing. Jour For. 1960, 58, 385-387.

47. Smit, C.; Kuijper, D.P.J.; Prentice, D.; Wassen, M.J.; Cromsigt, J.P.G.M. Coarse woody debris facilitates oak recruitment in Białowieża Primeval Forest, Poland. For. Ecol. Manag. 2012, 284, 133-141. [CrossRef]

48. Kota, A.M.; Bartos, D.L. Evaluation of Techniques to Protect Aspen Suckers from Ungulate Browsing in the Black Hills. West. J. Appl. For. Bethesda 2010, 25, 161-168. [CrossRef]

49. Pellerin, M.; Saïd, S.; Richard, E.; Hamann, J.-L.; Dubois-Coli, C.; Hum, P. Impact of deer on temperate forest vegetation and woody debris as protection of forest regeneration against browsing. For. Ecol. Manag. 2010, 260, 429-437. [CrossRef]

50. Tuley, G. The growth of young oak trees in shelters. For. Int. J. For. Res. 1985, 58, 181-195. [CrossRef]

51. Sharew, H.; Hairston-Strang, A. A Comparison of Seedling Growth and Light Transmission among Tree Shelters. North. J. Appl. For. 2005, 22, 102-110. [CrossRef]

52. Ward, J.S.; Gent, M.; Stephens, G. Effects of planting stock quality and browse protection-type on height growth of northern red oak and eastern white pine. For. Ecol. Manag. 2000, 127, 205-216. [CrossRef]

53. Barton, C.; Miller, J.; Sena, K.; Angel, P.; French, M. Evaluating the Use of Tree Shelters for Direct Seeding of Castanea on a Surface Mine in Appalachia. Forests 2015, 6, 3514-3527. [CrossRef]

54. Stange, E.E.; Shea, K.L. Effects of Deer Browsing, Fabric Mats, and Tree Shelters on Quercus rubra Seedlings. Restor. Ecol. 1998, 6, 29-34. [CrossRef]

55. Kochenderfer, J.N.; Ford, W.M. Utility of Wire Cages, Tree Shelters, and Repellents to Minimize Herbivory to Oak by White-Tailed Deer. Res. Pap. NRS-5; US Department of Agriculture, Forest Service, Northern Research Station: Madison, MA, USA, 2008. 
56. Taylor, T.S.; Loewenstein, E.F.; Chappelka, A.H. Effect of animal browse protection and fertilizer application on the establishment of planted Nuttall oak seedlings. New For. 2006, 32, 133-143. [CrossRef]

57. Keeton, W. Evaluation of Tree Seedling Mortality and Protective Strategies in Riparian Forest Restoration. North. J. Appl. For. 2008, 25, 117-123. [CrossRef]

58. Sweeney, B.W.; Czapka, S.J.; Petrow, L.C.A. How Planting Method, Weed Abatement, and Herbivory Affect Afforestation Success. South. J. Appl. For. 2007, 31, 85-92. [CrossRef]

59. Sweeney, B.W.; Czapka, S.J.; Yerkes, T. Riparian Forest Restoration: Increasing Success by Reducing Plant Competition and Herbivory. Restor. Ecol. 2002, 10, 392-400. [CrossRef]

60. Pinna, S.; Malenfant, A.; Cote, M. Vigor and Growth Responses of Sugar Maple and Yellow Birch Seedlings According to Different Competing Vegetation Types and Fabric Shelter Use. North. J. Appl. For. 2012, 29, 133-140. [CrossRef]

61. Clements, D.R.; Luginbill, S.; Jordan, D.A.; Van Dragt, R.; Pelant, R.K. Techniques to Promote Garry Oak Seedling Growth and Survival in Areas with High Levels of Herbivory and Competition. Northwest Sci. 2011, 85, 172-181. [CrossRef]

62. Burger, D.W.; Forister, G.W.; Kiehl, P. Height, Caliper Growth, and Biomass Response of Ten Shade Tree Species to Treeshelters. J. Arboric. 1996, 22, 161-166.

63. Trent, A.; Nolte, D.; Wagner, K. Comparison of Commercial Deer Repellents; Technology and Development Program; U.S. Department of Agriculture, Forest Service: Missoula, MT, USA, 2001.

64. Jacobs, W. Pesticides Federally Registered for Control of Terrestrial Vertebrate Pests. In Prevention and Control of Wildlife Damage; University of Nebraska-Lincoln: Lincoln, NE, USA, 1994.

65. Palmer, W.L.; Wingard, R.G.; George, J.L. Evaluation of White-Tailed Deer Repellents. Wildl. Soc. Bull. 1983, 11, 164-166.

66. Graveline, B.D.; Wells, G.R.; Schlarbaum, S.E.; Fribourg, H.A. Growth and protection of selected northern red oak seedlings planted on old field sites. Gen. Tech. Rep. South. Res. Serv. 1998, 20, 257-262.

67. Conover, M.R.; Kania, G.S. Effectiveness of human hair, BGR, and a mixture of blood meal and peppercorns in reducing deer damage to young apple trees. In Proceedings of the Third Eastern Wildlife Damage Control Conference, Gulf Shores, AL, USA, 18-21 October 1987; Holler, N.R., Christian, J.B., Eds.; University of Nebraska-Lincoln: Lincoln, NE, USA, 1987; pp. 97-101.

68. Andelt, W.F.; Burnham, K.P.; Baker, D.L. Effectiveness of Capsaicin and Bitrex Repellents for Deterring Browsing by Captive Mule Deer. J. Wildl. Manag. 1994, 58, 330-334. [CrossRef]

69. Kimball, B.A. Hydrolyzed casein reduces browsing of trees and shrubs by white-tailed deer. HortSci. Publ. Am. Soc. Hortic. Sci. 2005, 40, 1810-1814. [CrossRef]

70. MacGowan, B.J.; Severeid, L.; Skemp, F. Control of Deer Damage with Chemical Repellents in Regenerating Hardwood Stands. In Proceedings of the Black Walnut in a New Century, Proceedings of the 6th Walnut Council Research Symposium; Michler, C.H., Pijut, P.M., Sambeek, J.V., Coggeshall, M., Seifert, J., Woeste, K., Overton, R., Eds.; U.S. Department of Agriculture, Forest Service, Northern Research Station: St. Paul, MN, USA, 2004; Volume NC-243, pp. 127-133.

71. Gustafson, D. Controlled Release Technology: Development of a Slow Release Systemic Repellent for the Protection of Tree Seedlings from Deer (Selenium, Diffusion). Ph.D. Thesis, University of Washington, Seattle, WA, USA, 1983.

72. Bartolozzi, S.; Marca, O.; Notarangelo, M.; Racanelli, V.; Guerri, F.S. L'effetto di repellenti in un giovane ceduo di cerro. Georgofili 2017, 14, 121-132.

73. Szukiel, E. Ochrona odnowien lasu przed zwierztna (wyniki badan nowych srodkow ochrony). Sylwan 1996, 140, 99-111.

74. Burney, O.T.; Jacobs, D.F. Ungulate Herbivory of Boreal and Temperate Forest Regeneration in Relation to Seedling Mineral Nutrition and Secondary Metabolites. New For. 2013, 44, 753-768. [CrossRef]

75. George, J.F.; Powell, J. Deer Browsing and Browse Production of Fertilized American Elm Sprouts. J. Range Manag. 1977, 30, 357-360. [CrossRef]

76. Tripler, C.; Canham, C.; Inouye, R.; Schnurr, J. Soil nitrogen availability, plant luxury consumption, and herbivory by white-tailed deer. Oecologia 2002, 133, 517-524. [CrossRef] [PubMed]

77. Brinks, J.S.; Lhotka, J.M.; Barton, C.D.; Warner, R.C.; Agouridis, C.T. Effects of fertilization and irrigation on American sycamore and black locust planted on a reclaimed surface mine in Appalachia. For. Ecol. Manag. 2011, 261, 640-648. [CrossRef] 
78. Redick, C.H.; McKenna, J.R.; Carlson, D.E.; Jenkins, M.A.; Jacobs, D.F. Silviculture at establishment of hardwood plantations is relatively ineffective in the presence of deer browsing. For. Ecol. Manag. 2020, 474, 118339. [CrossRef]

79. Forkner, R.E.; Hunter, M.D. What Goes up Must Come down? Nutrient Addition and Predation Pressure on Oak Herbivores. Ecology 2000, 81, 1588-1600. [CrossRef]

80. Hunter, M.D.; Schultz, J.C. Fertilization mitigates chemical induction and herbivore responses within damaged oak trees. Ecology 1995, 76, 1226-1233. [CrossRef]

81. Scott, E.L. A Study of Pasture Trees and Shrubbery. Bull. Torrey Bot. Club 1915, 42, 451-461. [CrossRef]

82. Watt, A.S. On the Causes of Failure of Natural Regeneration in British Oakwoods. J. Ecol. 1919, 7, $173-203$. [CrossRef]

83. Maltoni, A.; Mariotti, B.; Tani, A.; Martini, S.; Jacobs, D.F.; Tognetti, R. Natural regeneration of Pinus pinaster facilitates Quercus ilex survival and growth under severe deer browsing pressure. For. Ecol. Manag. 2019, 432, 356-364. [CrossRef]

84. Underwood, N.; Inouye, B.D.; Hambäck, P.A. A Conceptual Framework for Associational Effects: When Do Neighbors Matter and How Would We Know? Q. Rev. Biol. 2014, 89, 1-19. [CrossRef]

85. Baraza, E.; Zamora, R.; Hódar, J.A. Conditional outcomes in plant-herbivore interactions: Neighbours matter. Oikos 2006, 113, 148-156. [CrossRef]

86. Gorchov, D.L.; Trisel, D.E. Competitive effects of the invasive shrub, Lonicera maackii (Rupr.) Herder (Caprifoliaceae), on the growth and survival of native tree seedlings. Plant Ecol. 2003, 166, 13-24. [CrossRef]

87. Owings, C.F.; Jacobs, D.F.; Shields, J.M.; Saunders, M.R.; Jenkins, M.A. Individual and interactive effects of white-tailed deer and an exotic shrub on artificial and natural regeneration in mixed hardwood forests. AoB Plants 2017, 9. [CrossRef] [PubMed]

88. Salek, L.; Harmacek, J.; Jerabkova, L.; Topacoglu, O.; Machar, I. Thorny Shrubs Limit the Browsing Pressure of Large Herbivores on Tree Regeneration in Temperate Lowland Forested Landscapes. Sustainability 2019, 11, 3578. [CrossRef]

89. Stokely, T.D.; Betts, M.G. Deer-Mediated Ecosystem Service versus Disservice Depends on Forest Management Intensity. J. Appl. Ecol. 2020, 57, 31-42. [CrossRef]

90. Andivia, E.; Villar-Salvador, P.; Oliet, J.A.; Puértolas, J.; Dumroese, R.K. How Can My Research Paper Be Useful for Future Meta-Analyses on Forest Restoration Plantations? New For. 2019, 50, 255-266. [CrossRef]

Publisher's Note: MDPI stays neutral with regard to jurisdictional claims in published maps and institutional affiliations.

(C) 2020 by the authors. Licensee MDPI, Basel, Switzerland. This article is an open access article distributed under the terms and conditions of the Creative Commons Attribution (CC BY) license (http://creativecommons.org/licenses/by/4.0/). 